\title{
Competences and Barriers for the Evidence-Based Practice in Nursing: an integrative review
}

\author{
Competências e barreiras para Prática Baseada em Evidências na Enfermagem: revisão integrativa \\ Competencias y barreras para Práctica Basada en Evidencias en la Enfermería: revisión integrativa
}

\section{Fernanda Carolina Camargo', Helena Hemiko Iwamoto', Cristina Maria Galvão", Gilberto de Araújo Pereira', Raymann Benzi Andrade', Giovanna Crispim Masso' \\ ' Universidade Federal do Triângulo Mineiro. Uberaba, Minas Gerais, Brazil. \\ "Universidade de São Paulo, Ribeirão Preto College of Nursing. Ribeirão Preto, São Paulo, Brazil.}

\section{How to cite this article:}

Camargo FC, Iwamoto HH, Galvão CM, Pereira GA, Andrade RB, Masso GC. Competences and Barriers for the Evidence-Based Practice in Nursing: An Integrative Review. Rev Bras Enferm [Internet]. 2018;71(4):2030-8.

DOI: http://dx.doi.org/10.1590/0034-7167-2016-0617

Submission: 12-21-2016

Approval: 07-24-2017

\section{ABSTRACT}

Objective: To analyze knowledge, attitudes, practices, and frequent barriers to the implementation of the Evidence-Based Practice among nursing assistants in the hospital. Method: This is an integrative review, whose search for primary studies occurred in the PubMed, CINAHL and LILACS databases. For the analysis, cross-sectional observational studies were included in English, Portuguese and Spanish, published in nursing journals, from January 2007 to July 2016. Results: The search resulted in 363 articles, including nine primary studies. The sources of recurrent evidence among care nurses were: personal experience and local care protocols. These professionals presented weaknesses in the implementation of the Evidence-Based Practice related to the lack of knowledge for evidence evaluation, work overload and resistance to change of practice. Final considerations Nurses presented favorable attitudes, however, with little knowledge to perform the Evidence-Based Practice. Results can support interventions for its implementation in the hospital.

Descriptors: Evidence-Based Nursing; Evidence-Based Clinical Practices; Hospitals; Clinical Nurses; Research in Nursing.

\section{RESUMO}

Objetivo: Analisar conhecimentos, atitudes, práticas e barreiras frequentes para a implementação da Prática Baseada em Evidências entre enfermeiros assistenciais no contexto hospitalar. Método: Trata-se de revisão integrativa, cuja busca dos estudos primários ocorreu nas bases PubMed, CINAHL e LILACS. Para análise foram incluídos estudos observacionais, tipo transversal, em inglês, português e espanhol, publicados em periódicos de enfermagem, no período de janeiro 2007 a julho 2016. Resultado: A busca resultou em 363 artigos, sendo incluídos nove estudos primários. As fontes de evidências recorrentes entre os enfermeiros assistenciais foram: a experiência pessoal e os protocolos assistenciais locais. Esses profissionais apresentaram fragilidades para a implementação da Prática Baseada em Evidências relacionadas ao pouco conhecimento para avaliação de evidências, sobrecarga de trabalho e resistência à mudança de práticas. Considerações finais: Enfermeiros apresentaram atitudes favoráveis, entretanto, pouco conhecimento para desempenharem a Prática Baseada em Evidências. Resultados podem subsidiar intervenções para sua implementação em âmbito hospitalar.

Descritores: Enfermagem Baseada em Evidências; Prática Clínica Baseada em Evidências; Hospitais; Enfermeiras Clínicas; Pesquisa em Enfermagem.

\section{RESUMEN}

Objetivo: Analizar conocimientos, actitudes, prácticas y barreras frecuentes para la implementación de la Práctica Basada en Evidencias entre enfermeros asistenciales en el contexto hospitalario. Método: Se trata de una revisión integrativa, cuya búsqueda de los estudios primarios ocurrió en las bases PubMed, CINAHL y LILACS. Para el análisis se incluyeron estudios observacionales, en corte transversal, en inglés, español, portugués y publicados en revistas de enfermería a partir del enero 2007 hasta el julio 2016. Resultado: La búsqueda resultó en 363 artículos, siendo incluidos nueve estudios primarios. Las fuentes de evidencia recurrentes entre los enfermeros asistenciales fueron: la experiencia personal y los protocolos asistenciales locales. Estos profesionales presentaron fragilidades para la implementación de la Práctica Basada en Evidencias relacionadas al poco conocimiento para evaluación de evidencias, sobrecarga de trabajo y resistencia al cambio de prácticas. Consideraciones 
finales: Los enfermeros presentaron actitudes favorables; sin embargo, tenían poco conocimiento para desempeñar la Práctica Basada en Evidencias. Los resultados pueden subsidiar intervenciones para su implementación en el ámbito hospitalario.

Descriptores: Enfermería Basada en Evidencias; Práctica Clínica Basada en Evidencias; Hospitales; Enfermeras Clínicas; Investigación en Enfermería.

\section{CORRESPONDING AUTHOR Fernanda Carolina Camargo E-mail: leticiapontes@ufpr.br}

\section{INTRODUCTION}

The teachings of Florence Nightingale (forerunner of Modern Nursing), were founders of the epistemological bases of Nursing and defend nurses applying scientific principles in the care of the patient in order to restore the general state of health, integrating nursing professional consciousness with its essence object: care $^{(1)}$. However, in the contemporaneousness of Brazilian hospital services, the transfer of research results to clinical practice is still a challenge $\mathrm{e}^{(2)}$. In particular, the critical use of these results, the appropriations of this information to the practice - here understood as its transference - still present barriers. In general, the transfer of research results to clinical practice promotes the improvement of the quality of care, by increasing the reliability of interventions, by increasing patient outcomes and reducing $\operatorname{costs}^{(3-9)}$.

Evidence-Based Practice (EBP) can be defined as a problemsolving approach to delivering health care that integrates the best evidence from well-delineated studies and care data, and matches patient preferences with values expertise of the health professional. The implementation of this approach in clinical practice is a process that includes seven steps.

Step 0: keep questioning attitude; stage 1: elaboration of the clinical question in the format that will produce the best and most relevant evidence; step 2: search and collection of the best and most relevant evidence to answer the clinical question; step 3: critical evaluation and overview of identified evidence; step 4: integration of the best evidence with the clinical expertise of the professional and the preferences and values of the patient to implement the clinical decision; step 5: evaluation of the clinical decision results implemented in practice or evidence-based change; and step 6: disseminate the results of clinical decision or change $\mathrm{e}^{(7)}$.

In a bibliometric study on EBP in Brazilian nursing journals, the results showed an increase in production related to this approach as of $2009^{(10)}$. However, there is a paradox at the national level. In spite of the increase in the body of research, due mainly to the expansion of the postgraduate in the area of Nursing, no significant impact was observed in the hospital practice, still focused on the development of tasks, by traditional conception or by medical subculture of care $\mathrm{c}^{(1-2,11)}$.

In particular, the use of research results by nursing workers favors breaking with non-systematized practices, anchored by reproduction or tradition. Considering that this contingent of workers is the largest in the hospital environment, transformations in the way of doing health impact on the organization as a whole. The transfer of research results to the nursing work contributes to intensify the critical judgment of professionals in front of the operational demands, as well as to favor the incorporation of innovations and safer decision-making for problems experienced in daily life $\mathrm{e}^{(5)}$.
In the international scenario, since the 1970s, there are initiatives for the use of research results in the nursing practice ${ }^{(2)}$. Despite the benefits, the incorporation of evidence into the clinical role of nurses has not yet reached the desired level ${ }^{(3)}$. There is a significant delay between the generation of research results and incorporation into clinical practice. In universities, the development of research is performed rigorously and for few, and health institutions present organizational culture with little support for this traverse ${ }^{(3,5-6)}$. Since, the traverse of knowledge is a relatively new theme and still little known in Brazil ${ }^{(11)}$. The concept of knowledge traverse is broad, because it includes the integration of knowledge users throughout the research process, integrates the strategies used at the end of the study to disseminate their results, and encourages their incorporation to be recommended, provided ethically and by reliable evidence ${ }^{(11)}$.

In recent international research, the authors discuss different models and strategies to expand the interpretive capacity of scientific evidence and its application among clinical practice nurses, namely, those professionals who perform their work at the bedside $\mathrm{e}^{(4-9)}$. This encouragement converges with the worldwide movement for improving the quality of health services that integrates patient safety, cost control and quality of care $^{(5-7)}$. Essentially, the actions aim to broaden competences and overcome barriers to the implementation of EBP.

For the present study, the definition of competence consists of the articulation between the concepts of Knowledge, Attitudes and Practices (KAP), being "Knowledge" the cognitive and comprehension domain; "Attitudes", the affective domain corresponding to the internalization of values; "Practices", the domain of skills, handling and creation, and barriers, the limiting aspects to action $^{(12)}$. Also, it is an understanding of competences and barriers to EBP proposed by the University of Texas Academic Center of Evidence-based Practice (USA), presented as a measurement of specific skills for the performance of this action, which is based on the identification and critical analysis of relevant publications, with the purpose of transforming this knowledge produced, through research or the conduction of specific research into a safe information for nurses' decision-making ${ }^{(13)}$.

Nurses' understanding of the Knowledge, Attitudes and Practices in the performance of EBP and the barriers they face is essential to enable the effective implementation of this approach in care settings. So that the recognition of the most common competences and barriers among nurses becomes strategic for the strengthening of EBP in the hospital. In the hospital scenario, efforts to make the implementation of EBP easier seek to reduce the complexity of the challenges for transferring scientific evidence to clinical practice. With the purpose of helping in decision-making of which model or strategy is more appropriate in this scenario, which is better for the professional, for the 
institution and that has greater potential in the resolution of clinical demands. It is essential to recognize KAP competence and barriers that the bedside nurses face in their daily lives ${ }^{(5)}$.

\section{OBJECTIVE}

To analyze in the literature what Knowledge, Attitudes, Practices and barriers are frequent in the implementation of EBP among nursing assistants in the hospital.

\section{METHOD}

It is an integrative review (IR), which is a methodological resource for gathering, evaluating and overviewing scientific evidence in nursing ${ }^{(14-16)}$. This method allows the inclusion for analysis of primary studies with different methodological approaches and research designs, not just randomized clinical trials as proposed in the systematic review ${ }^{(14-15)}$. The integrative review allows a critical evaluation of the evidences found and the characterization of the knowledge state of the subject of interest ${ }^{(14-15)}$.

The present IR was conducted in six stages, namely: research question for the development of the review; search in the literature of primary studies; extraction of data; evaluation of primary studies; interpretation of results; and presentation of the review ${ }^{(14)}$.

The research question delimited for the development of the review was: What Knowledge, Attitudes, Practices and barriers are frequent in the implementation of EBP among care nurses in the hospital? The PICO strategy ${ }^{(17)}$, in its PICOS variation ${ }^{(18)}$, was used to construct the study question to delimit the type of the primary studies. Being P of population (nursing assistants in the hospital), and I (intervention or area of interest) in the case Knowledge, Attitudes, Practices and obstacles for EBP. Element $\mathrm{C}$ (comparison between intervention and group) was not employed. For element $\mathrm{O}$ (outcome), evidence-based practice was considered, as described in the study question. Finally, for element S (study type), it was delimited in an observational cross-sectional study. It should be emphasized that the option for this type of study presents an intrinsic relation with the question of the review, since it is the topic of interest to identify the most frequent Knowledge, Attitudes, Practices and barriers among the care nurses in the hospital.

The databases selected were the PubMed (National Library of Medicine National Institutes of Health), CINAHL (Cumulative Index to Nursing and Allied Health Literature) and LILACS (Health Sciences of Latin America and the Caribbean). The choice of keywords was based on the concept of competences and barriers specific to EBP, and they were defined with greater sensitivity in the literature on the subject ${ }^{(12-13)}$. The controlled keywords used in English for PubMed and used in CINAHL were [Evidence-Based Nursing], [Nursing research]; and in Portuguese on LILACS: [Enfermagem Baseada em Evidências], [Prática Clínica Baseada em Evidências], [Pesquisa em Enfermagem]. As uncontrolled descriptors in English for PubMed and CINAHL were used [Nursing, Evidence-Based], [Nursing, Evidence Based]; in Portuguese on LILACS: [Atitudes], [Barreiras]. Searches took place in August 2016.
The keywords for PubMed and CINAHL were: [Evidence Based Nursing] or [Nursing, Evidence-Based] or [Nursing, Evidence Based] associated with Evidence-Based Practice and [Nursing research], and [Attitudes to research], and [Barriers]. For LILACS, the corresponding keywords were applied: [EvidenceBased Nursing] or [Evidence-Based Clinical Practice] associated with and [Nursing Research], and [Attitudes], and [Barriers]. However, as the search in LILACS for the cross-correlation of the corresponding keywords did not result in the identification of studies - therefore not sensitive - a broader strategy was undertaken by crossing the keywords in Portuguese [Enfermagem Baseada em Evidências] or associated [Prática Clínica Baseada em Evidências], and [Pesquisa em Enfermagem].

In order to identify the most frequent "competences" and barriers among the nursing staff, the present study opted to control the methodological design of the primary studies to be analyzed. For the analysis, cross-sectional observational studies were included in English, Portuguese and Spanish indexed in nursing journals from January 2007 to July 2016. The review studies, theoretical or reflective, editorial letters, studies performed in a specific unit or clinic, or in non-hospital settings.

The first selection of the primary studies was by reading the titles and abstract of the different reference lists identified in the databases, by independent pairs. The reference lists were comprehensive. They were delimited by the thorough reading and double checking of the abstracts, according to those that specifically addressed the area of interest of this IR, so as to include studies whose objectives were related to analysis on Knowledge, Attitudes, Practices and/or barriers to the implementation of EBP among nurses.

Subsequently, the primary studies were thoroughly read in detail. From this stage, the type of study was delimited, including cross-sectional observational studies - from the reading and double checking of the primary studies. Therefore, the investigated populations were delimited, excluding the primary studies that had the participation of nursing academics, nurse educators, managers, professors or researchers.

The manual search by reading the references of the included primary studies was also used and inserted those studies that included the inclusion criteria delimited in the review. Data extraction from primary studies was based on a tool used in the national literature ${ }^{(19)}$, considering the following aspects: publication data (authors and year), study objective, place of study, observational study method, sample, results and conclusion.

For the evaluation of the observational studies, a statement entitled Strengthening the Reporting of Observational Studies in Epidemiology (STROBE) was adopted, which consists of a checklist (22 items) with recommendations on the data that must be described at all stages of observational studies ${ }^{(20)}$. Each criterion received a score from zero to 1 , which was later transformed into a percentage, considering good quality primary studies with a percentage higher than $40 \%{ }^{(21)}$. Statistical results were presented according to data from the original study. As a criterion for the presentation of the results of the review, only the three most frequent aspects were used - in relative frequency or higher mean value; and the translation of the related terms occurred freely by the authors of this study. In the occurrence 
of limitations to calculate effect measures by the joint analysis of the results of primary studies, manual counting was used as strategy for the overview of the studies, that is to say, absolute frequency of similar terms, organizing the results into categories.

\section{RESULTS}

The search resulted in 363 articles, of which 79 were repeated between the different databases. Eight primary studies met the inclusion criteria, and the manual search allowed the inclusion of another research (Figure 1).

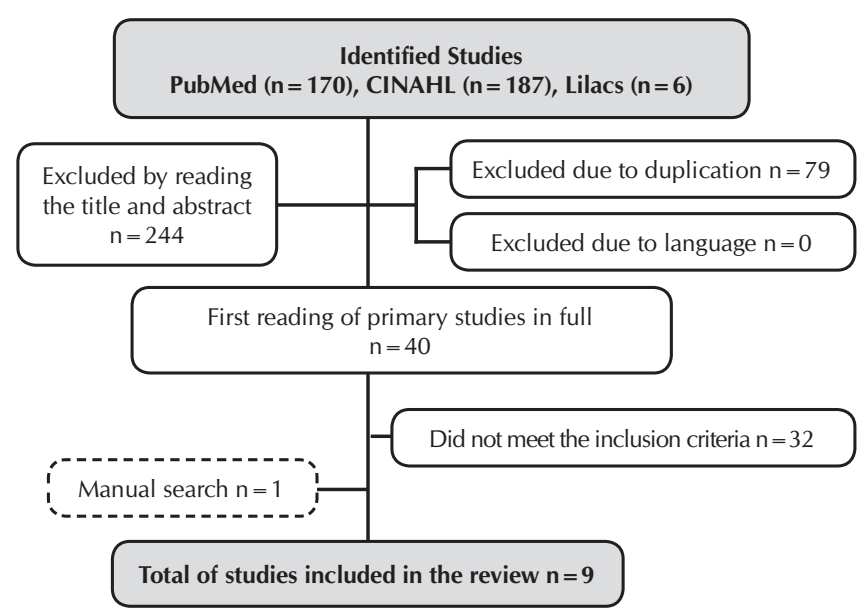

Figure 1 - Flowchart for selection of primary studies, Brazil, 2016

The nine primary studies included in the review were published in the following nursing journals, namely: Journal of Nursing Management $(n=2)$, Worldviews on Evidence-based
Nursing ( $n=2$ ) Journal of Nursing Scholarship $(n=1)$, BMC Health Services Research $(n=1)$, and BMC Health Services Research $(n=1)$. It should be emphasized that the last journal is not specific to nursing, however, the problem investigated in the primary study answers the question of the IR. The research was conducted by nurses and included through manual search. As for the temporal distribution of the research, it is observed that there is no linear trend pattern, with a higher concentration in the year $2008(n=4)$ (Figure 2).

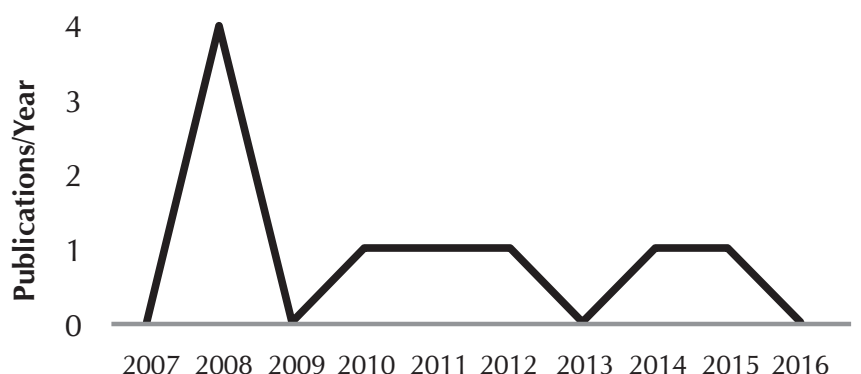

Figure 2 - Number of primary studies in each year for the delimited period (from January 2007 to July 2016), Brazil, 2016

In relation to the place of study, two studies were published both in the United States of America and in the United Kingdom. All the primary studies presented good quality ( $>40 \%$ ) in relation to the items proposed in the STROBE checklist (Chart 1).

After thorough reading of the primary studies included in the review, the aspects on KAP and more frequent barriers in each research were identified. The tabulation of this information was described in accordance with the data presented in each primary study by the authors (Chart 2).

Chart 1 - Characterization of primary studies included in the integrative review, Brazil, 2016

\begin{tabular}{|c|c|c|c|c|c|}
\hline Author (year) & Objective & Questionnaire & Sample & Place & STROBE \\
\hline $\begin{array}{l}\text { Rolfe et al. } \\
(2008)^{(22)}\end{array}$ & $\begin{array}{l}\text { To identify the ability of nurses to interpret scientific } \\
\text { evidence. }\end{array}$ & Created by the authors & $\mathrm{n}=189$ & $\begin{array}{l}\text { United } \\
\text { Kingdom }\end{array}$ & $63.6 \%$ \\
\hline $\begin{array}{l}\text { McCloskey } \\
(2008)^{(23)}\end{array}$ & $\begin{array}{l}\text { To identify the characteristics of nurses related to the } \\
\text { level of training, years of experience and performance in } \\
\text { the hospital that may interfere with the ability to evaluate } \\
\text { research, and in the Evidence-Based Practice. }\end{array}$ & $\begin{array}{l}\text { The Research Utilization } \\
\text { Questionnaire }\end{array}$ & $\mathrm{n}=270$ & $\begin{array}{l}\text { United State } \\
\text { of America }\end{array}$ & $68.2 \%$ \\
\hline \begin{tabular}{c|} 
Bonner e \\
Sando $(2008)^{(24)}$
\end{tabular} & $\begin{array}{l}\text { To identify knowledge, attitude and use of research by } \\
\text { nurses. }\end{array}$ & $\begin{array}{c}\text { Edmonton Research Orientation } \\
\text { Survey }\end{array}$ & $\mathrm{n}=347$ & Australia & $54.5 \%$ \\
\hline $\begin{array}{l}\text { Ofi et al. } \\
(2008)^{(25)}\end{array}$ & $\begin{array}{l}\text { To investigate knowledge of nurses in the evaluation of } \\
\text { research, attitudes and barriers to its use. }\end{array}$ & $\begin{array}{l}\text { The Research Utilization } \\
\text { Questionnaire }\end{array}$ & $\mathrm{n}=500$ & Nigeria & $77.3 \%$ \\
\hline $\begin{array}{l}\text { Mashiach } \\
\text { Eizenberg } \\
(2010)^{(26)}\end{array}$ & $\begin{array}{l}\text { To identify relationships between the professional and } \\
\text { personal characteristics of nurses for the Evidence-Based } \\
\text { Practice. }\end{array}$ & $\begin{array}{c}\text { Attitudes Towards Research in } \\
\text { nursing } \\
\text { Barriers to Evidence-based Nursing } \\
\text { Practice }\end{array}$ & $\mathrm{n}=243$ & Israel & $68.2 \%$ \\
\hline $\begin{array}{l}\text { Gerrish et al. } \\
(2011)^{(27)}\end{array}$ & $\begin{array}{l}\text { To identify factors that influence and promote Evidence- } \\
\text { Based Practice among caregivers. }\end{array}$ & $\begin{array}{l}\text { Self-reported Developing Evidence- } \\
\text { based Practice Questionnaire }\end{array}$ & $\mathrm{n}=855$ & $\begin{array}{l}\text { United } \\
\text { Kingdom }\end{array}$ & $95.5 \%$ \\
\hline $\begin{array}{l}\text { Dalheim et al. } \\
(2012)^{(28)}\end{array}$ & $\begin{array}{l}\text { To determine factors that influence the Evidence-Based } \\
\text { Practice in a university hospital. }\end{array}$ & $\begin{array}{l}\text { Self-reported Developing Evidence- } \\
\text { based Practice Questionnaire }\end{array}$ & $\mathrm{n}=407$ & Norway & $86.4 \%$ \\
\hline $\begin{array}{l}\text { Heydari et al. } \\
(2014)^{(29)}\end{array}$ & $\begin{array}{l}\text { To identify Knowledge, Attitudes, and Practices for } \\
\text { Evidence-Based Practice. }\end{array}$ & Evidence Based Practice & $\mathrm{n}=240$ & Iran & $63.6 \%$ \\
\hline $\begin{array}{l}\text { Wilson et al. } \\
(2015)^{(30)}\end{array}$ & $\begin{array}{l}\text { Identify the organizational and individual aspects that } \\
\text { may influence the nursing Evidence-Based Practice. }\end{array}$ & $\begin{array}{l}\text { Information Literacy for Evidence- } \\
\text { Based Nursing Practice }\end{array}$ & $n=1977$ & $\begin{array}{l}\text { United State } \\
\text { of America }\end{array}$ & $72.7 \%$ \\
\hline
\end{tabular}


Chart 2 - Frequent aspects extracted from the primary studies on Knowledge, Attitudes, Practices and barriers to the implementation of the Evidence-Based Practice among nursing assistants in the hospital, Brazil, 2016

\begin{tabular}{|c|c|c|c|c|}
\hline Author & Aspects* & $\mathrm{n}(\%)$ & Mean(sd) & Likert $^{\mathrm{b}}$ \\
\hline \multicolumn{5}{|c|}{ Most used sources of evidence } \\
\hline \multirow[t]{3}{*}{ Rolfe et al..$^{(22)}$} & Reflection on own experience in the care & $200(93.9)^{a}$ & - & - \\
\hline & Co-workers & $190(89.2)^{a}$ & - & - \\
\hline & Intuition & $174(81.7)^{a}$ & - & - \\
\hline \multirow{3}{*}{$\begin{array}{l}\text { Dalheim et } \\
\text { al. } .^{(28)}\end{array}$} & Guidelines information & $705(82.9)^{a}$ & - & - \\
\hline & Information on graduate programs & $658(77.2)^{a}$ & - & - \\
\hline & Local protocol information & $620(72.9)^{a}$ & - & - \\
\hline \multirow{3}{*}{$\begin{array}{l}\text { Gerrish et } \\
\text { al. }{ }^{(29)}\end{array}$} & Information I learned about each patient & - & $4.3(0.8)$ & 5 \\
\hline & My personal experience in caring for patients & - & $4.1(0.7)$ & 5 \\
\hline & Information I get from local policies and protocols & - & $4.1(0.7)$ & 5 \\
\hline \multicolumn{5}{|c|}{ Knowledge. Attitudes and Practices } \\
\hline \multirow[t]{3}{*}{ McCloskey ${ }^{(23)}$} & Research helps to build scientific bases for Nursing knowledge & - & $4.0(0.92)$ & 5 \\
\hline & Research is necessary for the continuous improvement of & - & $4.0(0.91)$ & 5 \\
\hline & I would change my practice according to scientific evidence & - & $3.9(1.04)$ & 5 \\
\hline \multirow[t]{3}{*}{ Ofi et al. ${ }^{(25)}$} & Research usually contributes to advances in nursing care & $455(91.0)^{a}$ & - & - \\
\hline & Nursing practice should be evidence-based & $438(87.6)^{a}$ & - & - \\
\hline & Knowledge about research values nursing practice & $433(86.6)^{a}$ & - & - \\
\hline Heydari et al. ${ }^{(29)}$ & Evidence-Based Practice Favoring Attitude & $221(92.1)$ & & \\
\hline \multicolumn{5}{|l|}{ Barriers } \\
\hline \multirow[t]{3}{*}{ McCloskey ${ }^{(23)}$} & I have time to read some resarch while on duty & - & $1.7(0.936)$ & 5 \\
\hline & Nursing research is conducted in my care area & - & $2.4(1.12)$ & 5 \\
\hline & My co-workers draw my attention to current research & - & $2.7(1.12)$ & 5 \\
\hline \multirow{3}{*}{$\begin{array}{l}\text { Bonner \& } \\
\text { Sando }^{(24)}\end{array}$} & Understanding the research design & $124(37.4)$ & - & - \\
\hline & Ethical review & $122(36.6)$ & - & - \\
\hline & Statistics & $91(27.3)$ & - & - \\
\hline \multirow[t]{3}{*}{ Ofi et al..$^{(25)}$} & Statistical analyses are not comprehensible & $250(50.0)^{a}$ & - & - \\
\hline & Implications for practice are unclear & $178(35.6)^{a}$ & - & - \\
\hline & Research is not reported clearly & $132(26.4)^{a}$ & - & - \\
\hline \multirow[t]{3}{*}{$\begin{array}{l}\text { Gerrish et } \\
\text { al. }{ }^{(27)}\end{array}$} & $\begin{array}{l}\text { Work overload during daily care actions makes it difficult to incorporate } \\
\text { evidence into practice }\end{array}$ & $432(51.1)^{a}$ & - & - \\
\hline & My workload is too heavy for me to be able to influence practice as I would like & $333(39.3)^{a}$ & - & - \\
\hline & There are not enough resources to be effective in promoting Evidence-Based Practice & $270(31.8)^{a}$ & - & - \\
\hline \multirow{3}{*}{$\begin{array}{l}\text { Dalheim et } \\
\text { al. }{ }^{(28)}\end{array}$} & My team's culture is not receptive to changes of practices. & - & $3.8(0.8)$ & 5 \\
\hline & I do not know how to do proper research search & - & $3.4(1.1)$ & 5 \\
\hline & I do not have authority in my workspace to propose changes & - & $3.3(0.8)$ & 5 \\
\hline \multirow{2}{*}{$\begin{array}{l}\text { Heydari et } \\
\text { al. }{ }^{(29)}\end{array}$} & Little knowledge and skills for evidence-based practice & $215(89.6)^{a}$ & - & - \\
\hline & Practice Evidence-Based Practice & $199(83.3)^{a}$ & - & - \\
\hline Author & Aspects* & Regression $(\beta)$ & $\begin{array}{c}\text { OR } \\
\text { Cl95\% } \\
\end{array}$ & $p$ \\
\hline \multirow{6}{*}{$\begin{array}{l}\text { Mashiach } \\
\text { Eizenberg(26) }\end{array}$} & Research skills & - & $(1.3-2.3)$ & 0.00 \\
\hline & Knowledge of bibliography & - & $(1.6-3.9)$ & 0.00 \\
\hline & Formal education & - & $(1.4-7.5)$ & 0.01 \\
\hline & Research Support & - & $(1.1-2.1)$ & 0.02 \\
\hline & Support from co-workers and the organization & - & $(0.2-0.7)$ & 0.01 \\
\hline & Experience of acting & - & $(1.0-2.9)$ & 0.04 \\
\hline
\end{tabular}


Chart 2 (concluded)

\begin{tabular}{|c|c|c|c|c|c|}
\hline Author & Aspects* & $\mathbf{n}(\%)$ & \multicolumn{2}{|c|}{ Mean(sd) } & Likert $^{\mathbf{b}}$ \\
\hline \multirow{6}{*}{$\begin{array}{c}\text { Wilson et } \\
\text { al. }^{(30)}\end{array}$} & History of having participated in research project & 7.6 & - & - & 0.0001 \\
\hline & Frequent need for information to practice & 2.9 & - & - & 0.0001 \\
\hline & Not understanding the search process & -1.5 & - & - & 0.0001 \\
\hline & Difficulty in understanding the scientific article & -1.8 & - & - & 0.0001 \\
\hline & Realize that nurses do not wish to change practice & 0.6 & - & - & 0.001 \\
\hline & Difficulty in finding research & -0.7 & - & - & 0.004 \\
\hline
\end{tabular}

Note: *Free translation; aParticipants could mark different options in a single question; Likert Scale measure.

Table 1 - Overview of primary studies according to the absolute frequency of similar terms related to Knowledge, Attitudes, Practices and barriers to the implementation of the Evidence-Based Practice among care nurses in the hospital, Brazil, 2016

\begin{tabular}{|c|c|c|}
\hline Dimensions & $\mathbf{n}^{\mathrm{c}}$ & Authors \\
\hline \multicolumn{3}{|l|}{ Most used sources of evidence } \\
\hline Personal experience & 3 & Rolfe et al. ${ }^{(22)}$; Gerrish et al. ${ }^{(27)}$; Dalheim et al. ${ }^{(28)}$ \\
\hline Local protocols & 3 & \\
\hline \multicolumn{3}{|l|}{ Knowledge, Attitudes and Practices } \\
\hline Research contributes to the advancement of Nursing & 2 & McCloskey ${ }^{(23)}$; Ofi et al. ${ }^{(25)}$ \\
\hline Assistance practice should be evidence-based & 2 & \\
\hline \multicolumn{3}{|l|}{ Barriers } \\
\hline Work overload & 3 & McCloskey ${ }^{(23)}$; Gerrish et al. ${ }^{(27)}$; Heydari et al. ${ }^{(29)}$ \\
\hline Nurses do not wish to change practice & 3 & Dalheim et al. ${ }^{(28)}$; Heydari et al.(29); Wilson et al. ${ }^{(30)}$; \\
\hline Do not understand the research design & 3 & Bonner \& Sando ${ }^{(23)}$; Heydari et al. ${ }^{(28)}$; Wilson et al. ${ }^{(29)}$ \\
\hline Do not understand the statistical analyses & 3 & Bonner \& Sando ${ }^{(24)}$; Ofi et a.I(25); Heydari et al..$^{(29)}$ \\
\hline
\end{tabular}

Note: Absolute frequency of similar terms identified in primary studies

The authors used different questionnaires to collect information (Chart 1), both for the conduction of primary studies and for the use of diversified tabulations of the data (Chart 2). Such employment was a limiting factor for the calculation of measures of global effect on KAP and determinant barriers. In the present review, a manual for counting the most frequent similar terms was adopted as a strategy for the overview of some research. Frequency delineation was based on the number of primary studies in which the term was used (Table 1).

\section{DISCUSSION}

Work dissatisfaction, overload and burnout among nurses have been discussed worldwide ${ }^{(31)}$. Hospital administrators should focus more on this problem and implement local strategies to mediate this reality. Efforts should focus on guiding these professionals as priorities for action in order to reduce the overlap of tasks $\mathrm{s}^{(6,31)}$. In a study carried out in Colombia, the authors pointed out that in the hospital accreditation process, EBP has been considered as an indicator of the quality of clinical practice ${ }^{(6)}$.

In view of the more frequent similar terms identified in this integrative review for KAP and barriers to the implementation of EBP, it can be inferred that the difficulties for nurses to use the results of research for decision making in clinical practice refer to the lack of knowledge about how identify the best scientific evidence and apply them in practice in order to generate propositional changes. The obstacles to the use of knowledge produced in nursing were focused, as a priority, on the understanding of research results ${ }^{(24,29-30)}$.

Although it is expected that nurses will use research critically, with a view to the evolution of nursing practice and health, not always, in the work process the transfer of research results to the practice is considered as one of the activities of this professional. Investments are required in a new administrative work structure, based on the availability of resources and realignment of activities for permanent research, organizational culture supporting practical changes to the use of scientific evidence, as a process of incorporation of innovations ${ }^{(5-6,31)}$.

In the United Kingdom, care nurses did not feel prepared for the critical consumption of research results and incorporation into practice, and those with a higher academic degree were more competent for $\mathrm{EBP}^{(27)}$. One way to overcome the barriers among care nurses was to support the support given by supervisors or other nursing leaders to use research results ${ }^{(28-29)}$. The age of the nurse, the length of time and the years since obtaining the last titration interfered in the way of searching for evidence and in identifying barriers to the implementation of $\mathrm{EBP}^{(28)}$.

Among Israeli care nurses, the implementation of EBP was facilitated when there was easy access to libraries rich in medical and nursing journals and when there was access to computers at the workplace. The level of training, the ability to identify different sources of evidence, and institutional support for searching and reading articles were the predictive variables for $\mathrm{EBP}^{(26)}$.

The results of the study carried out with Nigerian nursing nurses recommend that hospitals maintain easy access to 
scientific journals, educational interventions such as discussion groups and review of the basic curriculum for nurse training with a view to increasing the competence of these nurses in incorporating scientific evidence in the clinical practice ${ }^{(25)}$.

In a research conducted in Australia, most care nurses presented a positive perception for EBP with increased use of research results. Although the geographical location of the study is distant from the main metropolitan centers, it did not constitute a barrier between the participants to access the research results ${ }^{(24)}$.

On the other hand, an investigation carried out with the health care nurses of the UK Health System revealed the existence of contradictions in the understanding of EBP in relation to what is proposed in the literature. The results also showed that there are important gaps in the understanding of these professionals despite the 15 years of discussion of this approach ${ }^{(22)}$.

In the United States of America, in a study carried out in five hospitals, the results showed differences between KAP and EBP related between the time of performance and the level of training of nursing assistants. Those with higher education presented more facilitating factors to EBP, so that continuing education was an important factor in the hospital structure for the use of research results in clinical practice, as well as in the establishment of a monitoring and evaluation system for $\mathrm{EBP}^{(23)}$. Collaboration among teachers, researchers and care nurses was also pointed out as a relevant initiative for the implementation of EBP, especially in teaching hospitals in the United States of America ${ }^{(8)}$.

It should be noted that in the search conducted in the databases, no IR was identified on the topic of interest, which evaluated competences and more frequent barriers to EBP among nurses in the hospital. Despite the recent bibliometric review pointing to an increase in national production in nursing journals on EBP, most of the studies included presented a theoretical-reflexive or qualitative approach $(84.9 \%)^{(10)}$. After conducting the present review, it can be inferred that there is a gap in the production of observational studies on KAP and barriers to the implementation of the EBP carried out in Brazil or in Latin America, allowing questions if this reality occurs due to the absence of valid tools or by the EBP still be an incipient construct, generating a greater challenge for developing countries.

After all, conceived by the "nightingalean" principles, nursing has already emerged as a logically organized science: research methodologies and statistical analyses to be deployed in direct care actions for health recovery and maintenance of life - a science understood as practice of effect. So that the conciliation between the research and the acting in the nursing make up its ontological essence ${ }^{(1)}$.

\section{Study limitations}

Regarding the limitations of this review, it is understood that other primary studies could be identified through searches in other databases, as well as the inclusion of studies published in periodicals from different health areas. In contrast, the main databases for health (PubMed) and nursing (CINAHL) were selected. The results of the present integrative review evidenced gaps in the scientific production of cross-sectional, observational studies to identify knowledge, attitudes, practices and frequent barriers in the implementation of EBP among nursing assistants in the hospital, considering the number of included studies for this RI. Another aspect relates to the fact that different questionnaires were carried out in the primary studies to obtain this information, making it impossible to calculate measures of effect by the joint analysis of the results of the primary studies. Most of the observed observational studies presented more than five years of publication, and it is important to stimulate the conduction of new researches to recognize if there were changes KAP to EBP in the hospital over time.

\section{Contribuições para a área da enfermagem, saúde ou política pública}

In general, the results of this review can support the design of intervention models that better enable the implementation of EBP in the hospital environment. Interventions should consider expanding nurses' personal skills to understand the investigations, and, motivational to the transformation of clinical practice. In relation to the organization, interventions should be directed to facilitate access to scientific sources and change in the work process to ensure time spent by research nurses. With this, they contributed to the increase of national and international production on the theme.

\section{FINAL CONSIDERATIONS}

Although hospital nurses have favorable attitudes towards EBP and believe that research contributes to the advancement of Nursing - having an evidence-driven role from scientific research is a challenge at the global level; considering that the most frequent terms found as sources of evidence most used by hospital nurses: personal experience and local care protocols. In many cases, professionals presented weaknesses in the implementation of this approach, related to the lack of knowledge for evidence evaluation, work overload and resistance to change of practices.

It is suggested to increase research on the theme for the recognition and comparison of these factors (KAP and barriers) in different localities worldwide in order to identify similarities that can support global strategies for the transfer of research results to the nursing side of the bed hospital - an act qualified by critical judgment and that guarantees greater security to the people, families and assisted communities. However, the results of this integrative review may support the design of more proactive interventions for the implementation of the Evidence-Based Practice among nurses in the hospital environment.

\section{REFERENCES}

1. Carvalho V. Research lines in nursing: phylosophical and epistemological highlights. Rev Bras Enferm[Internet]. 2015 [cited 2016 Nov 17];68(4):723-9. Available from: http://www.scielo.br/pdf/reben/v68n4/0034-7167-reben-68-04-0723.pdf

2. Carvalho EC, Laus AM, Caliri MHL, Rossi LG. From the production to the use of research results in care practice: a consolidating 
experience. Rev Bras Enferm[Internet]. 2010[cited 2016 Nov 17];63(5):853-8. Available from: http://www.scielo.br/pdf/reben/ v63n5/27.pdf

3. Melnyk BM, Fineout-Overholt E, Gallagher-Ford L, Kaplan L. The State of Evidence-based practice in US nurses: critical implication for nurse's leaders and educators. J Nurs Adm[Internet]. 2012[cited 2016 Nov 17];42(9):410-17. Available from: http://downloads. Iww.com/wolterskluwer_vitalstream_com/journal_library/nna_00020443_2012_42_9_410.pdf

4. Mollon D, Fields W, Gallo AM, Wagener R, Soucy J, Gustafson B, et al. Staff practice, attitudes and knowledge/skills regarding evidence-based practice before and after an Educational Intervention. J Cont Educ Nurs[Internet]. 2012[cited 2016 Nov 17];43(9):4119. Available from: https://www.ncbi.nlm.nih.gov/pubmed/22816384

5. Melnyk BM, Gallagher-Ford L, Long LE, Fineout-Overholt E. The Establishment of Evidence-Based Practice Competencies for practicing registered Nurses and Advanced Practice Nurses in real-world clinical settings: proficiencies to improve healthcare quality, reliability, patient outcomes and costs. Worldviews Evid Based Nurs[Internet]. 2014[cited 2016 Nov 21];11(1):5-15. Available from: http://onlinelibrary.wiley.com/doi/10.1111/wvn.12021/full

6. DeBruyn RR, Ochoa-Marín SC, Semenic S. Barriers and facilitators to Evidence-Based Nursing in Colombia: perspective of nurse educators, nurse researchers and graduate students. Invest Educ Enferm[Internet]. 2014[cited 2016 Nov 21];32(1):9-21. Available from: http://www.scielo.org.co/pdf/iee/v32n1/v32n1a02.pdf

7. Melnyk BM, Fineout-Overholt E, Stillwell SB, Williamson KM. The seven steps of evidence-based practice. Am J Nurs[Internet]. 2010[cited 2016 Nov 21];110(1):51-3. Available from: https://www.ncbi.nlm.nih.gov/pubmed/20032669

8. Edward KL. A model for increasing appreciation, accessibility and application of research in Nursing. J Prof Nurs[Internet]. 2015[cited 2016 Nov 17];31(2):119-23. Available from: https://www.ncbi.nlm.nih.gov/pubmed/25839951

9. Kim SC, Brown CE, Ecoff L, Davidson JE, Gallo AM, Klimpel K, et al. Regional evidence-based practice fellowship program: impact on Evidence-based practice implementation and barriers. Clin Nurs Res[Internet]. 2013[cited 2016 Nov 17];22(1):51-69. Available from: https://www.ncbi.nlm.nih.gov/pubmed/22645401

10. Camargo FC, Garcia LAA, Santos AS, Iwamoto HH. Evidence-based practice: bibliometric review of national publications in nursing journals. REFACS[Internet]. 2017[cited 2016 Nov 17];5(Spec):429-39. Available from: http://seer.uftm.edu.br/revistaeletronica/ index.php/refacs/article/view/2137/pdf

11. Oelke ND, Lima MADS, Acosta AM. Knowledge translation: translating research into policy and practice. Rev Gaúcha Enferm[Internet]. 2015[cited 2016 Nov 17];36(3):113-7. Available from: http://seer.ufrgs.br/index.php/RevistaGauchadeEnfermagem/article/view/55036

12. Hunker DF, Gazza EA, Shellenbarger T. Evidence-based Knowledge, Skills and Attitudes for scholarly writing development across all levels of Nursing Education. J Prof Nurs[Internet]. 2014[cited 2016 Nov 17];30(4):341-6. Available from: https://linkinghub. elsevier.com/retrieve/pii/S8755-7223(13)00189-0

13. Stevens KR. ACE Star Modelo of EBP: knowledge transformation. Academic Centre for evidence practice. The University of Texas Health Science Centre at San Antonio. 2004.

14. Whittemore R, Knafl K. The integrative review: update methodology. J Adv Nurs[Internet]. 2005[cited 2016 Nov 17];52(5):546-53. Available from: https://www.ncbi.nlm.nih.gov/pubmed/16268861

15. Mendes KDS, Silveira RCCP, Galvão CM. Revisão integrativa: método de pesquisa para a incorporação de evidências na saúde e na enfermagem. Texto Contexto Enferm[Internet]. 2008[cited 2016 Nov 17];17(4):758-64. Available from: http://www.scielo.br/ pdf/tce/v17n4/18.pdf

16. Freitas SF, Silveira RCCP, Clark AM, Galvão CM. Surgical count process for prevention of retained surgical items: an integrative review. J Clin Nurs[Internet]. 2016[cited 2016 Nov 17];25(13-14):1835-47. Available from: https://www.ncbi.nlm.nih.gov/pubmed/27104785

17. Santos CMC, Pimenta CAM, Nobre MRC. The Strategy PICO paragraph construction of the question of search and search for evidence. Rev Latino-Am Enferm[Internet]. 2007[cited 2016 Nov 17];15(3):508-11. Available from: http://www.scielo.br/pdf/rlae/ v15n3/v15n3a23.pdf

18. Centre for Reviews and Dissemination-CRD. Systematic Reviews CRD's Guidance for Undertaking Reviews in Health Care [Internet]. York: Centre for Reviews and Dissemination, University of York. 2009[cited 2016 Nov 17]. Available from: https://www.york.ac.uk/ media/crd/Systematic_Reviews.pdf

19. Ursi, ES, Galvão CM. Perioperative prevention of skin injury: an integrative literature review. Rev Latino-Am Enfermagem[Internet]. 2006[cited 2016 Nov 17];14(1):124-31. Available from: http://www.scielo.br/pdf/rlae/v14n1/v14n1a17.pdf

20. Malta M, Cardoso LO, Bastos Fl, Magnanini MMF, Silva CMFP. Strobe Initiative: grants paragraph communication observational studies. Rev Saúde Pública[Internet]. 2010[cited 2016 Nov 17];44(3):1-5. Available from: http://www.scielo.br/pdf/rsp/v44n3/en_21.pdf

21. Almeida MCV, Cezar-Vaz MR. Scientific evidence of dockworker illness to nursing clinical reasoning. Rev Esc Enferm USP[Internet]. 2016[cited 2016 Nov 17];50(2):341-49. Available from: http://www.scielo.br/pdf/reeusp/v50n2/0080-6234-reeusp-50-02-0346.pdf

22. Rolfe G, Segrott J, Jordan S. Tensions and contradictions in nurses' perspectives of evidence-based practice. J Nurs Manag[Internet]. 2008[cited 2016 Nov 17];16(4):440-51. Available from: https://www.ncbi.nlm.nih.gov/pubmed/18405261

23. McCloskey DJ. Nurses' perceptions of research utilization in a corporate health care system. J Nurs Scholarsh[Internet]. 2008[cited 2016 Nov 17];40(1):39-45. Available from: https://www.ncbi.nlm.nih.gov/pubmed/18302590 
24. Bonner A, Sando J. Examining the knowledge, attitude and use of research by nurses. J Nurs Manag[Internet]. 2008[cited 2016 Nov 17];16(3):334-43. Available from: https://www.ncbi.nlm.nih.gov/pubmed/18324993

25. Ofi B, Sowunmi L, Edet D, Anarado N. Professional nurses' opinion on research and research utilization for promoting quality nursing care in selected teaching hospitals in Nigeria. Int J Nurs Pract[Internet]. 2008[cited 2016 Nov 17];14(3):243-55. Available from: https://www.ncbi.nlm.nih.gov/pubmed/18460066

26. Eizenberg MM. Implementation of evidence-based nursing practice: nurses' personal and professional factors? J Adv Nurs[Internet]. 2008[cited 2016 Nov 17];67(1):33-42. Available from: https://onlinelibrary.wiley.com/doi/abs/10.1111/j.1365-2648.2010.05488.x

27. Gerrish K, Guillaume L, Kirshbaum M, McDonnell A, Tod A, Nolan M. Factors influencing the contribution of advanced practice nurses to promoting evidence-based practice among front-line nurses: findings from a cross-sectional survey J Adv Nurs[Internet]. 2011 [cited 2016 Nov 17];67(5):1079-90. Available from: https://onlinelibrary.wiley.com/doi/abs/10.1111/j.1365-2648.2010.05560.x

28. Dalheim A, Harthug S, Nilsen RM, Nortvedt MW. Factors influencing the development of evidence-based practice among nurses: a self-report survey. BMC Health Serv Res[Internet]. 2012[cited 2016 Nov 17];12(367). Available from: https://www.ncbi.nlm.nih. gov/pmc/articles/PMC3557178/

29. Heydari A, Mazlom SR, Ranjbar H, Scurlock-Evans L. A study of Iranian nurses' and midwives' knowledge, attitudes, and implementation of evidence-based practice: the time for change has arrived. Worldviews Evid Based Nurs[Internet]. 2014[cited 2016 Nov 17];11(5):325-31. Available from: https://sigmapubs.onlinelibrary.wiley.com/doi/abs/10.1111/wvn.12052

30. Wilson M, Sleutel M, Newcomb P, Behan D, Walsh J, Wells JN, et al. Empowering nurses with evidence-based practice environments: surveying Magnet ${ }^{\circledR}$, pathway to Excellence ${ }^{\circledR}$, and non-magnet facilities in one healthcare system. Worldviews Evid Based Nurs[Internet]. 2015[cited 2016 Nov 17];12(1):12-21. Available from: https://sigmapubs.onlinelibrary.wiley.com/doi/abs/10.1111/wvn.12077

31. You LM, Aiken LH, Sloane DM, Liu K, He GP, Hu Y, et al. Hospital nursing, care quality, and patient satisfaction: cross-sectional surveys of nurses and patients in hospital in China and Europe. Int J Nurs Stud[Internet]. 2013[cited 2016 Nov 17];50(2):154-61. Available from: https://linkinghub.elsevier.com/retrieve/pii/S0020-7489(12)00156-3 